\title{
IGF Binding Protein-3 Treatment Alters Intestinal Cell Proliferation But Not Body Weight of Adult Cystic Fibrosis Transmembrane Conductance Regulator Deficient Mice
}

\author{
JUAN CARLOS CANALE-ZAMBRANO, AND CHRISTINA K. HASTON \\ Department of Human Genetics [J.C.C.-Z., C.K.H.], Department of Medicine [C.K.H.], Meakins-Christie Laboratories, McGill University, \\ Montreal, Quebec H2X 2P2, Canada
}

\begin{abstract}
The intestinal phenotype of cystic fibrosis (CF) transmembrane conductance regulator deficient mice includes altered cell homeostasis and a distended crypt-villus axis, which, in previous work, was inversely proportional to body weight. To investigate this correlation, herein, we treated $\mathrm{CF}$ mice with IGF binding protein-3 (IGFBP-3), a protein which, as it has potent effects on cell proliferation and apoptosis, we hypothesized would alter the intestinal cell homeostasis, and assessed body weight. Six-week-old C57BL/ 6JxBALB F2 CF and WT mice received recombinant human IGFBP-3 (rhIGFBP-3, $20 \mathrm{mg} / \mathrm{kg}$ ) or vehicle treatment, and weight gain, serum protein levels, and intestinal histology were assessed. Administration of rhIGFBP-3 to CF mice significantly increased the number of Igfbp-3 positive cells in the intestine and partially reversed the hyperproliferative phenotype of intestinal crypts and muscularis externa, while not affecting apoptosis. Serum Igfbp-3 levels were increased, and Igf-I, albumin, and triglycerides measures were decreased in CF compared with WT mice. rhIGFBP-3 treatment significantly increased serum albumin and triglycerides but did not affect weight gain in CF mice. We have identified rhIGFBP-3 treatment to reduce intestinal cell proliferation, resulting in decreases in crypt depth and muscularis externa thickness in CF mice. (Pediatr Res 69: 129-134, 2011)
\end{abstract}

$\mathrm{C}$ ystic fibrosis $(\mathrm{CF})$ is caused by mutations in the $\mathrm{CF}$ transmembrane conductance regulator (CFTR) gene and is a common, lethal autosomal recessive disease principally affecting Caucasians (1). One of the pathologies of CF is intestinal disease, which is presumed to be caused by reduced water secretion in this organ and which results in the development of meconium ileus in 15-20\% of CF newborns and distal intestinal obstruction syndrome episodes in $25 \%$ of $\mathrm{CF}$ adults (1). CF patients also have a lower BMI than those without $\mathrm{CF}$ and this is influenced by lung, intestinal, and pancreatic diseases and nutritional status (1).

Mouse models wherein Cftr has been knocked out have been evaluated to investigate the mechanisms through which mutations in Cftr produce intestinal disease and may contribute to the growth defect. Specifically, $C f t^{\text {tm1Unc }}$ mice are smaller than their littermates and develop an intestinal phenotype resembling meconium ileus characterized by mucous build up and lethal intestinal plugs (2). Kent et al. (3), using a liquid diet that reduced the incidence of the lethal intestinal complication, reported the intestinal crypts of older CF mice to be distended and the mucosal thickness of the intestine to be increased relative to non-CF littermates. In addition, we previously assessed the relationship of the $\mathrm{CF}$ growth defect to intestinal disease in a population of genetically mixed CF mice and showed crypt elongation, due to an expanded proliferative zone and decreased apoptosis, to inversely correlate with body weight (4).

The histological changes evident in the intestines of $\mathrm{CF}$ mice are consistent with the mitogenic effects increased levels of Igf-I have on this tissue, suggesting the IGF pathway may be perturbed in CF mice. In detail, increases in Igf-I achieved through recombinant protein administration (5) or transgenesis (6) have been shown to enhance crypt cell mitosis, crypt depth, villus height, and intestinal mucosal and muscularis mass and to decrease the apoptotic index in animal models while strong overexpression of the Igf-I receptor, Igf-Ir, has been demonstrated to occur in colorectal carcinoma (7). Igf-I is regulated by a family of proteins, known as the IGF-binding proteins (IGFBPs), which modulate Igf-I action either by presenting Igf-I to its receptor or by sequestering the peptide and reducing receptor interaction (8). Igfbp-3 accounts for $80 \%$ of IGF binding in the circulation (9) and may modulate Igf-I action in the intestine (10). Independent of the Igf-I interaction, increased levels of Igfbp- 3 have been shown to inhibit the proliferation of intestinal smooth muscle cells (11) and to induce apoptosis in colonic adenoma-derived cells (12).

We hypothesized that the antiproliferative or proapoptotic actions of Igfbp-3 would attenuate the hyperproliferative phenotype that characterizes the intestines of CF mice, and as a consequence, improve body weight. To investigate this hypothesis, we treated $\mathrm{CF}$ and non-CF mice with recombinant human IGFBP-3 (rhIGFBP-3) and measured its effects systemically and on the intestinal phenotype.
Abbreviations: B6, C57BL/6J; CF, cystic fibrosis; CVA, crypt-villus axis; IGF-Ir, IGF I receptor; rhIGFBP-3, recombinant human IGF binding protein 3; IGFBP, IGF binding protein 


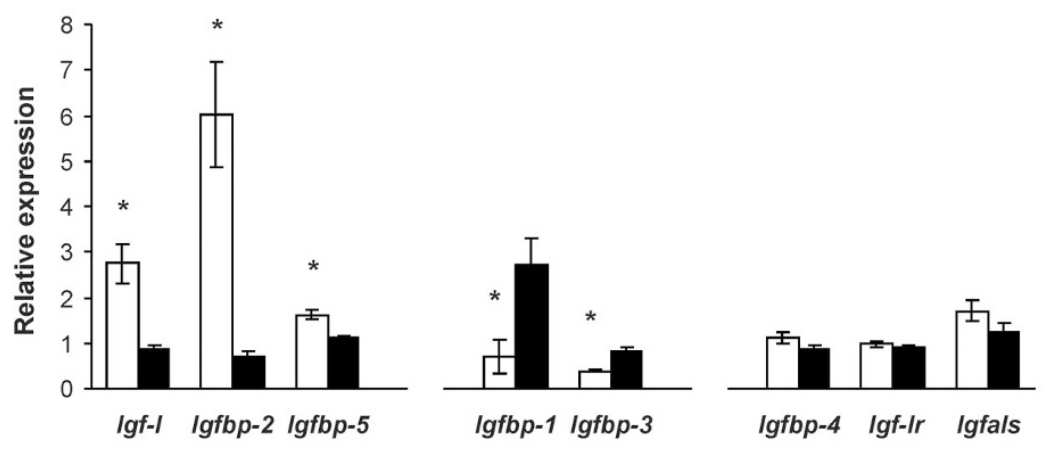

Figure 1. Expression of IGF pathway genes in B6xBALB F2 CF ( $\square$ ) and WT (ם) mice. RNA was isolated from ileal tissue harvested from 10-wk-old mice at necropsy. Expression relative to the Atx10 reference gene is presented as the mean $\pm \mathrm{SE}(n=11-12$ mice/group $) . *$ indicates a significant difference between groups, $p<$ 0.05 .

\section{MATERIALS AND METHODS}

Mice. C57BL/6J (B6)xBALBc/J F2 Cftr ${ }^{\mathrm{tm} 1 \mathrm{UNC}}(\mathrm{F} 2 \mathrm{CF})$ and WT littermate $\left(\mathrm{Cftr}^{+/+}\right)$mice were derived from a cross of B6 $\mathrm{Cftr}^{+/-}$to BALB Cftr ${ }^{+/-}$ mice through two generations of breeding. Mice were housed and genotyped as in (4) and maintained on liquid diet (Peptamen) from the age of $21 \mathrm{~d}$ until sacrifice at the age of $10 \mathrm{wk}$. At the same time, on each experimental endpoint day, the body weight of each mouse was measured, the mice were anesthetized by intraperitoneal delivery of sodium pentobarbital, and killed by exsanguination. These studies were completed under a protocol approved by the McGill University Animal Care Committee.

IGFBP-3. rhIGFBP-3 was the generous gift of Insmed Incorporated (Richmond, VA). Six-week-old mice received rhIGFBP-3 $(20 \mathrm{mg} / \mathrm{kg}$, diluted in acetate buffer) through i.p. injections once a day for 28 consecutive days. Similar doses of this protein have been shown to influence colorectal tumor growth in vivo (13). The control group was injected with acetate buffer once daily for 28 consecutive days. The four groups used in this study were CF mice treated with rhIGFBP-3, CF mice receiving vehicle, WT mice treated with rhIGFBP-3, and WT mice receiving vehicle.

Quantitative real-time PCR. Total RNA was extracted from $1 \mathrm{~cm}$ of the terminal ileum according to the manufacturer's (Sigma Chemical Co., Oakville, Canada) instructions. To generate the cDNA for real-time PCR, 3 $\mu \mathrm{g}$ of total RNA from each tissue sample was reverse transcribed as in Ref. 14. We performed Taqman relative quantification on Igf-I, Igf-Ir, Igfals (IGFBP and acid labile subunit), Igfbp-1, 2, 3, 4, and 5 using methods previously described (14).

Serum phenotype. Blood from the cardiac puncture was stored in serum separator tubes and centrifuged. Total serum Igf-I and Igfbp-3 levels were determined by ELISA using commercially available kits from R\&D Systems (Minneapolis, MN). Serum samples were assessed for glucose, albumin, and triglycerides levels using a biochemistry analyzer Hitachi 911.

Histology. At dissection, the entire small intestine was removed, flushed with PBS, and a $10-15 \mathrm{~cm}$ portion of the terminal small intestine was fixed in $10 \%$ buffered formalin and submitted for standard histological processing. Swiss roll paraffin-embedded sections $(5 \mu \mathrm{m})$ were stained with hematoxylin and eosin, and the crypt-villus axis (CVA) length was measured as in Ref. 4. For muscle thickness, the muscularis externa layer was measured at 50 regular intervals throughout the small intestine. All sections were scored by an observer blinded to mouse Cftr genotype and treatment.

Immunohistochemistry. Staining was completed as described in Ref. 4 using antibodies against proliferating cell nuclear antigen (PCNA, sc-9857, dilution 1:100), Igf-Ir $\beta$ (sc-713, dilution 1:600), and Igfbp-3 (sc-9028, dilution 1:500; Santa Cruz Biotechnology, Santa Cruz, CA), and Caspase-3 (1:75, Cell Signaling Technology) were used as in Ref. 4. TUNEL staining was completed as described previously (15). Blinded scoring of an average of 20 CVA per mouse was performed and presented as the average number of positively stained cells per CVA or percentage of positive stained cells of total crypt cells for PCNA staining.

Phenotypic data analysis. Tests for differences between groups of mice defined by genotype, treatment, or sex were completed with $t$ test and with the Wilcoxon signed-rank test, where $p \leq 0.05$ was considered significant. The $p$ values from the $t$ test are reported as statistical significance, where evident, occurred after either test.

\section{RESULTS}

Expression of IGF pathway genes is altered in intestines of $\boldsymbol{C F}$ mice. To investigate whether genes of the IGF family are altered in expression in the $\mathrm{CF}$ intestine, we assayed the level of Igf-I and related genes in this tissue. As shown in Figure 1, the intestinal expression of $I g f-I$ and its binding proteins 2 and 5 was increased, whereas the levels of binding proteins 1 and 3 were decreased in the intestines of $\mathrm{CF}$ compared with WT mice. The expression of Igf-Ir, Igfbp-4, and IGFBP acid labile subunit did not differ between CF and WT mice.

rhIGFBP-3 treatment increases numbers of Igfbp-3 positive cells in intestinal tissue. The decreased intestinal expression of $I g f b p-3$ with increased Igf-I suggests the proliferative response of the $\mathrm{CF}$ intestine could be due in part to increased bioavailability of Igf-I. To investigate this, we treated $\mathrm{CF}$ and non-CF mice with rhIGFBP-3, during a period of $28 \mathrm{~d}$, and measured the $\mathrm{CF}$ intestinal disease phenotype.

As shown in Figure 2, the recombinant protein treatment effectively increased the number of Igfbp- 3 positive cells in the intestines of CF and WT mice compared with those receiving the vehicle control $(p<0.040)$. Numbers of cells positive for the Igf-I receptor were not affected by the protein treatment $(p=0.66)$; however, the number of cells positive for the phosphorylated (i.e. activated) form of the Igf-I receptor was found to be decreased in rhIGFBP-3-treated CF mice $(p=0.003)$.

rhIGFBP-3 treatment decreases crypt depth and muscle thickness in CF mice. To investigate whether altered levels of Igfbp-3 influenced the CF intestinal distension phenotype, histological measures were made. As shown in Figure 3, and in agreement with previous reports (2-4), the CF intestinal mucosa was distended and muscularis externa layer increased compared with WT mice. This distension was partially reversed by the administration of rhIGFBP-3, which decreased the CVA length significantly $(p=0.011)$, primarily due to $\sim 25 \%$ reduction of the crypt depth $(p=0.002)$, in CF mice (Fig. $3 A$ and $B$ ). The thickness of the intestinal muscularis externa layer was also reduced by rhIGFBP- 3 treatment $(p=$ 0.004; Fig. $3 A$ and $C$ ).

rhIGFBP-3 treatment decreases crypt cell proliferation but not apoptosis in CF mice. Increased levels of Igfbp-3 have been shown to inhibit proliferation (11) or to promote apoptosis (16) in vitro; therefore, to investigate the mechanism through which the decrease of CVA length occurred in rhIGFBP3-treated CF mice, immunohistochemistry with proliferative and apoptotic markers was performed. The decreased CVA length in rhIGFBP-3-treated mice was mainly due to reduced 

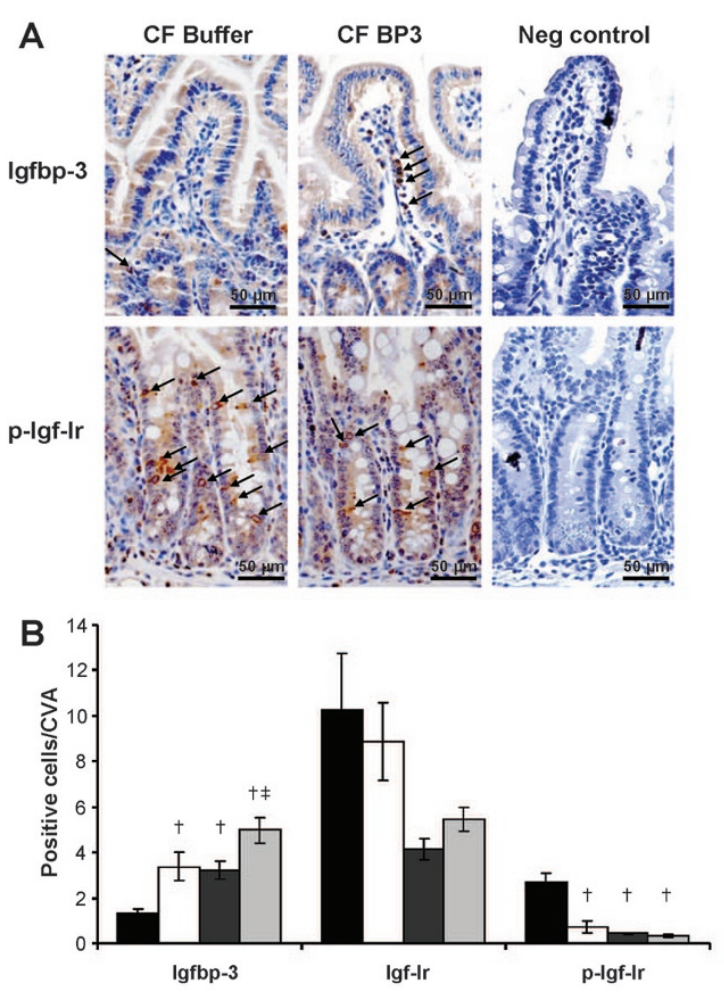

Figure 2. Immunohistochemical evaluation of IGF pathway proteins in ileal tissue of rhIGFBP-3 or vehicle-treated B6xBALB F2 CF mice. Tissue harvested from 10-wk-old mice was stained for Igfbp-3, Igf-Ir, and phosphorylated Igf-I receptor, p-Igf-Ir. (A) Representative immunostaining of CF ileal tissue. Arrows indicate positive staining. Original magnification of $\times 400$. For negative control sections, the primary antibody was excluded. $(B)$ Number of positively stained cells per CVA for CF mice treated with rhIGFBP-3 ( $\square$ ), CF mice injected with diluent buffer $(\square)$, WT mice treated with rhIGFBP-3 ( $\square$ ), and WT mice treated with diluent buffer $(\square)$. Data are presented as the mean $\pm \mathrm{SE}(n=4-6$ mice/group $)$; $\dagger$ indicates a significant difference compared with $\mathrm{CF}$ mice injected with diluent buffer and $\ddagger$ a significant difference compared with WT mice injected with diluent buffer.

proliferation of crypt cells in rhIGFBP-3-treated versus vehicle-treated CF mice ( $p=0.035$; Fig. $4 A$ and $B$ ) while numbers of apoptotic cells were not significantly altered $(p=0.2$; Fig. $4 C$ and $D$ ). The findings for caspase-3 staining were supported with TUNEL staining (data not shown).

rhIGFBP-3 treatment-related changes in blood biochemistry. To determine whether rhIGFBP-3 treatment affected systemic levels of Igf-I or Igfbp-3, the serum levels of these proteins were measured. As shown in Figure 5A, Igf-I was lower in serum from CF versus non-CF mice $(p=0.003)$ as has been reported for CF patients (17) and CF mice (18), whereas Igfbp-3 levels were significantly increased $(p=$ 0.002). Serum levels of Igfbp-3 have not been reported for CF mice, whereas in $\mathrm{CF}$ patients, these measures have been shown to be lower (17) or unaltered (19); neither measure was significantly altered by rhIGFBP-3 treatment.

As an assessment of the nourishment level in these mice serum albumin was assayed and as previous studies report lower serum triglycerides in CF mice $(4,20)$, we determined whether the treatment affected this phenotype. The serum levels of albumin and triglycerides were found to be lower in CF compared with WT mice $(p=0.0007$ and $p=0.02$,

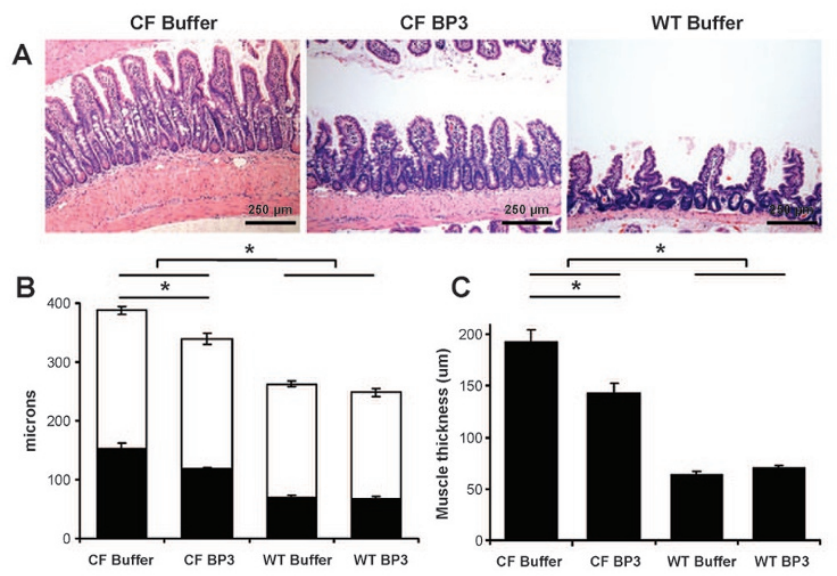

Figure 3. Intestinal histology of rhIGFBP-3 or vehicle-treated CF and WT mice. Mice received rhIGFBP-3 or vehicle daily for $4 \mathrm{wk}$, and intestinal tissue was harvested from 10-wk-old B6xBALB F2 CF mice after killing. (A) Representative sections of ileal tissue stained with hematoxylin and eosin. Original magnification of $\times 100$. (B) CVA height (villus $\square$; crypt $\square$ ) and (C) muscle thickness were measured by image analysis of histological sections. $\mathrm{CF}$, WT buffer $=\mathrm{CF}$ and WT mice injected with diluent buffer. CF, WT $\mathrm{BP} 3=\mathrm{CF}$ and WT mice treated with rhIGFBP-3. Data are presented as the mean $\pm \mathrm{SE}(n=8-13 \mathrm{mice} /$ group $) ; *$ indicates a significant difference between groups, $p<0.05$.

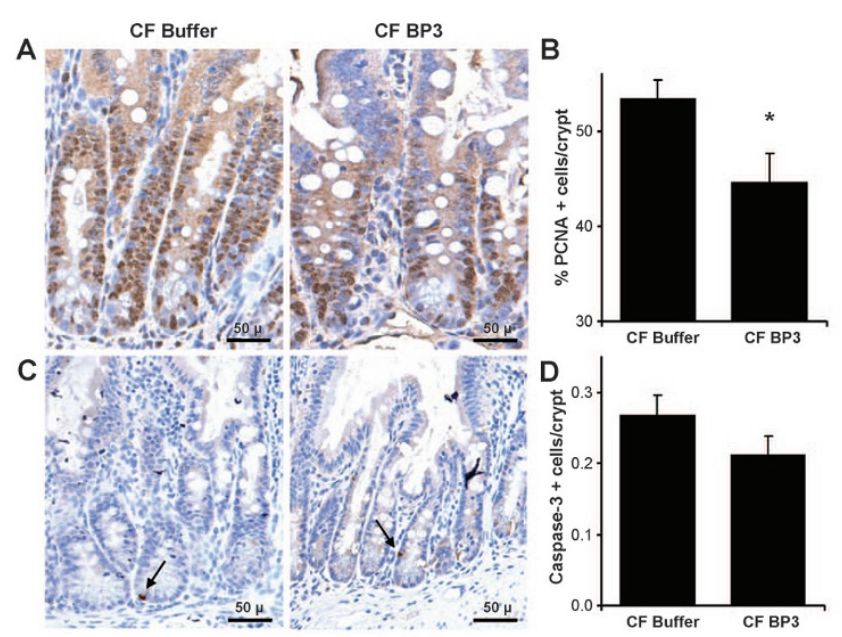

Figure 4. rhIGFBP-3 treatment decreases crypt cell proliferation but not apoptosis in B6xBALB F2 CF mice. Intestinal tissue as in Figure 3 was stained with $(A)$ PCNA or $(C)$ active caspase-3. Groups as defined in Figure 3. $(B$ and $D)$. The numbers of positive cells per unit CVA were counted and are presented as the mean $\pm \mathrm{SE}(n=7-10 \mathrm{mice} /$ group $) ; *$ indicates a significant difference between groups, $p<0.05$.

respectively) and to increase by administration of rhIGFBP-3 in CF mice ( $p=0.03$ and $p=0.015$, respectively; Fig. $5 B$ and $C)$. The serum levels of glucose did not differ among mice grouped by $C f t r$ genotype or rhIGFBP-3 treatment (Fig. 5D). No differences in serum protein levels by sex were identified (data not shown).

rhIGFBP-3 treatment and body weight gain. As we had previously determined body weight to be inversely correlated with CVA length in B6xBALB F2 CF mice (4), we next assessed whether rhIGFBP-3 treatment changed the weight gain. As shown in Figure 6, the treatment did not affect total body weight gain in CF mice. However, in the WTs, vehicle 


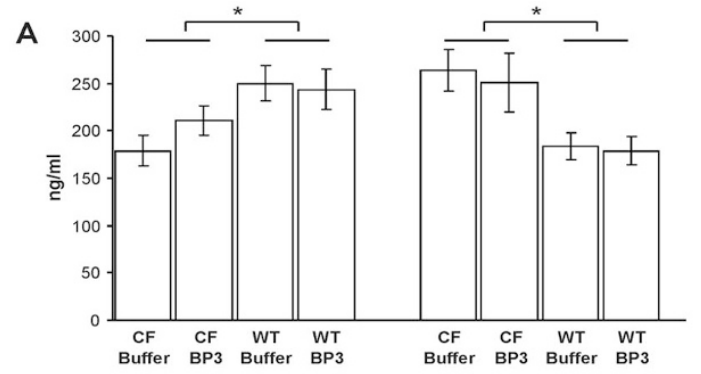

B

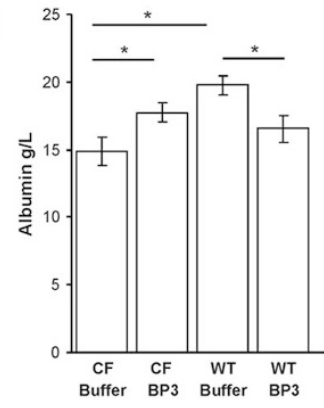

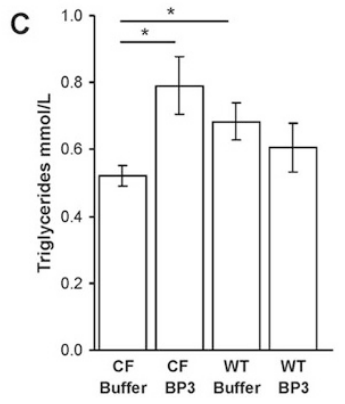

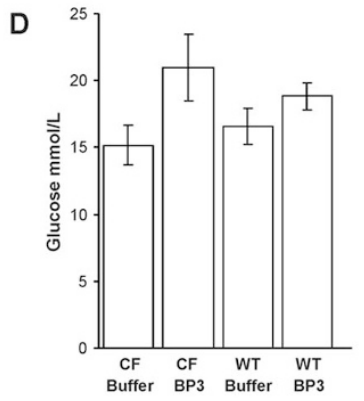

Figure 5. IGF pathway proteins and serum biochemistry of rhIGFBP-3 or vehicle-treated B6xBALB F2 CF and WT mice. Mice received rhIGFBP-3 or vehicle daily for $4 \mathrm{wk}$, and blood was drawn from 10-wk-old mice by cardiac puncture at killing. Serum Igf-I $(A$, left $)$ and Igfbp-3 ( $A$, right $)$ were measured by ELISA, and serum biochemistry $(B-D)$ on a Hitachi 911 analyzer. Groups as defined in Figure 3. Data are presented as the mean $\pm \mathrm{SE}(n=11-13$ mice/ group); * indicates a significant difference between groups, $p<0.05$.
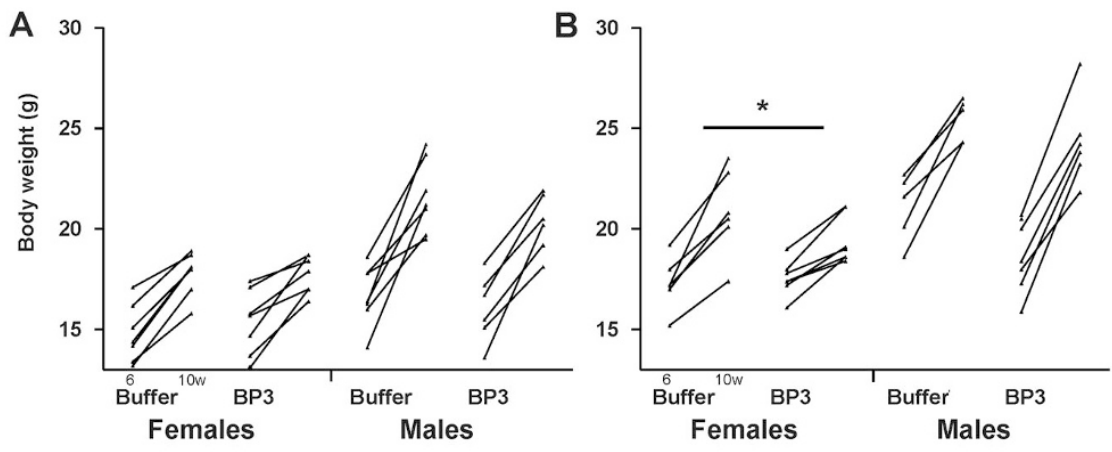

Figure 6. Effect of rhIGFBP-3 or vehicle treatment on weight gain in B6xBALB F2 CF and WT mice. The body weight of each mouse at age of $6 \mathrm{wk}$ and after $4 \mathrm{wk}$ of treatment with rhIGFBP-3 or vehicle (10 wk) is given by sex and $\mathrm{CF}$ status for $(A) \mathrm{CF}$ and $(B)$ WT mice. Buffer $=$ mice injected with diluent buffer. $\mathrm{BP} 3=$ mice treated with rhIGFBP-3. $n=5$ or 6 mice/group; $*$ indicates a significant difference between groups, $p<0.05$. control-treated female mice gained more weight over the $4 \mathrm{wk}$ than rhIGFBP-3-treated mice $(p=0.036)$.

\section{DISCUSSION}

In this work, we demonstrate the altered proliferative response that results in CVA distension and increased muscularis thickness in the intestines of $\mathrm{CF}$ mice to be partially reversed by rhIGFBP-3 treatment, which may have inhibited Igf-Ir activation in the CF intestinal crypt cells. This treatment also increased the serum levels of albumin and triglycerides in $\mathrm{CF}$ mice but produced no clear evidence of effects on $\mathrm{CF}$ mouse body weight.

The changes in IGF pathway gene expression measured in the $\mathrm{CF}$ intestine are consistent with those of models of adaptive growth of the intestine. Specifically, the intestinal phenotype of CF mice histologically resembles that of rats after major small bowel resection wherein changes in the ileum include muscle wall hypertrophy and villus enlargement (21). Igfbp-3 mRNA levels in the intestine are decreased after major small bowel resection (22) or after postfast refeeding, where the decrease coincides with a similar growth response in the intestinal mucosa (10). Second, Gillingham et al. (23) reported increased expression of $I g f-1$ and $I g f b p-5$, which were also more highly expressed in the $\mathrm{CF}$ intestine, in sections of intestinal growth of a jejunoileal resection model. Increased intestinal expression of $I g f b p-5$ has also been reported in response to induced Igf-I levels $(6,23)$, which also produce increased intestinal mucosa and muscularis, as was detected in the CF mice of the current study.

Administration of rhIGFBP-3 reduced the CVA distension and the thickness of the muscularis layer in the CF intestine, but whether this occurred through Igf-I-dependent or independent actions is not clear. The finding that rhIGFBP-3 treatment reduces the number of proliferative cells in the CF intestine agrees well with the reports of decreased keratinocyte proliferation in the skin of Igfbp-3 transgenic mice (24) and of systemic administration of rhIGFBP-3 significantly inhibiting tumor growth in a mouse model of colon cancer (13). Regarding mechanism, evidence for an Igf-I-dependent effect of Igfbp-3 on crypt cell proliferation and the muscularis layer is the observation that rhIGFBP-3 treatment also decreased the number of intestinal epithelial cells with the phosphorylated Igf-I receptor. As this form of the receptor indicates Igf-I binding (25), the reduction in the number of cells positive for the phosphorylated Igf-I receptor would similarly indicate reduced Igf-I action in the treated mice, which exhibited a lessened proliferative response. It is also possible that Igf-I-independent actions of Igfbp-3, which also inhibit proliferation (9), could have occurred. 
In contrast to the effects on the proliferative response of the intestine, rhIGFBP-3 treatment did not alter serum Igf-I or Igfbp-3 levels and did not significantly augment the weight gain of the CF mice, suggesting a local effect of the treatment to have occurred independently of the systemic effect. The circulating levels of Igf-I were lower, whereas those of Igfbp-3 were higher in CF mice, which is the opposite of the endogenous expression of these proteins in the intestine, suggesting that tissue-specific rather than systemic alterations of the IGF system are responsible for the hyperproliferative state in CF intestine. Supporting this, Vrieling et al. (26) reported IGF axis gene expression in colorectal tissue to be independent of serum IGF levels. The response of the intestine as separate from body weight was also evident in glucagonlike peptide- 2 treatment of mice after ileocecal resection that altered intestinal proliferation but not weight gain (27) and by data where intestinal growth due to exogenous IGF-I was observed in both Igfbp-5 deficient and WT mice, whereas weight gain was only evident in the WT mice (28). Despite this support, it is also possible that exogenous rhIGFBP-3 treatment could have an effect earlier in the growth period and thus was not manifested when given to 6-wk-old mice.

The functional significance of the distended CVA in CF remains to be determined. Herein, we demonstrate that an intervention to reduce the CVA does not improve body weight; therefore, the intestinal changes may indicate the existence of altered epithelial cell proliferation in the CF condition or may reflect a tissue response to bacteria (29), which are overgrown in the CF intestine (30,31). rhIGFBP-3 treatment, as it decreased CVA length and muscle thickness, may be beneficial in ameliorating the intestinal propensity to develop mucous plugs, given the increased numbers of goblet cells in the distended villus and the decreased motility in the $\mathrm{CF}$ intestine (32). Further investigation is needed.

An effect on body weight was evident as WT females treated with rhIGFBP-3 gained less weight than those which were vehicle treated. As perturbations of the IGF axis have been shown to have sex-dependent effects on body weight, possibly by influencing adipose tissue size (33), we speculate that this mechanism, rather than effects on intestinal histology that did not differ between these groups, created the difference in weight gain. The rhIGFBP-3 had more of an effect in WT females than in CF female mice may be due to the higher serum Igf-I levels in the WT mice, which could affect the action of the injected protein.

The low levels of serum albumin and triglycerides in the CF mice of this study indicates a compromised nutrition level and reduced lipid absorption (20), both of which were ameliorated by rhIGFBP-3 treatment. A positive association between increased IGFBP-3 levels and each of serum triglycerides (34) and albumin levels (35) has been reported, but a causal mechanism linking these measures, if such exists, is unknown. Igfbp-3 is known to interact with transcription factors retinoid-X-receptor-alpha or peroxisome proliferator-activated receptor gamma (9) whose actions lead to increased plasma triglycerides (36); therefore, this pathway, although not evaluated in the current work, may have augmented the serum triglyceride levels in rhIGFBP-3-treated CF mice. The in- crease in serum albumin and triglyceride levels suggests an improved nutritional state in the Igfbp-3-treated CF mice, although this was not reflected in weight gain. Therefore, it is possible that these protein levels are in advance of weight gain or reflect biochemical changes in serum induced by the exogenous Igfbp-3.

Finally, this study was completed in mice of a mixed genetic background, B6xBALB F2, to build on our previous observation of intestinal distention as correlated to body weight (4), which was made in CF mice of this background. One limitation created by the use of F2 mice is the possibility that the phenotypic changes (decreased CVA, muscle mass, and proliferation) are due to differences in genetic background between rhIGFBP-3 and vehicle-treated mice. The probability that our two populations (rhIGFBP-3 and vehicle-treated mice) comprised mice which each have the disparate genotypes at the locus responsible for the observed phenotypes (or any one locus) is, however, extremely low $\left(\sim 10^{-8}\right)$, making the phenotypic differences observed due to treatment and not genetic background. A second potential limitation of this work is that the mice were fed with a liquid diet to avoid the complication of lethal mucous plugs in the intestine. As this diet may be anti-inflammatory (37), and thus could obscure this feature of the CF intestine and influence the IGF bioactivity (19), it is possible the absolute action of rhIGFBP-3 in this system was affected by the diet. The effects of rhIGFBP-3 treatment reported here as relative to vehicle-treated mice are, however, independent of diet that was common for all mice.

In summary, we report the hyperproliferative intestinal phenotype of CF mice to include the altered expression of IGF pathway genes, and for the rhIGFBP-3 treatment to partially reverse this response in both the crypts and muscularis layer of this tissue. However, altering the proliferative response did not affect the weight gain of adult B6xBALB F2 CF mice, suggesting these CF phenotypes to be distinct.

\section{REFERENCES}

1. O'Sullivan BP, Freedman SD 2009 Cystic fibrosis. Lancet 373:1891-1904

2. Snouwaert JN, Brigman KK, Latour AM, Malouf NN, Boucher RC, Smithies O, Koller BH 1992 An animal-model for cystic-fibrosis made by gene targeting. Science 257:1083-1088

3. Kent G, Oliver M, Foskett JK, Frndova H, Durie P, Forstner J, Forstner GG, Riordan JR, Percy D, Buchwald M 1996 Phenotypic abnormalities in long-term surviving cystic fibrosis mice. Pediatr Res 40:233-241

4. Canale-Zambrano JC, Poffenberger MC, Cory SM, Humes DG, Haston CK 2007 Intestinal phenotype of variable-weight cystic fibrosis knockout mice. Am J Physiol Gastrointest Liver Physiol 293:G222-G229

5. Steeb CB, Shoubridge CA, Tivey DR, Read LC 1997 Systemic infusion of IGF-I or LR(3)IGF-I stimulates visceral organ growth and proliferation of gut tissues in suckling rats. Am J Physiol 272:G522-G533

6. Williams KL, Fuller CR, Fagin J, Lund PK 2002 Mesenchymal IGF-I overexpression: paracrine effects in the intestine, distinct from endocrine actions. Am J Physiol Gastrointest Liver Physiol 283:G875-G885

7. Donovan EA, Kummar S 2008 Role of insulin-like growth factor-1R system in colorectal carcinogenesis. Crit Rev Oncol Hematol 66:91-98

8. Firth SM, Baxter RC 2002 Cellular actions of the insulin-like growth factor binding proteins. Endocr Rev 23:824-854

9. Jogie-Brahim S, Feldman D, Oh Y 2009 Unraveling insulin-like growth factor binding protein-3 actions in human disease. Endocr Rev 30:417-437

10. Winesett DE, Ulshen MH, Hoyt EC, Mohapatra NK, Fuller CR, Lund PK 1995 Regulation and localization of the insulin-like growth-factor system in small-bowel during altered nutrient status. Am J Physiol 268:G631-G640

11. Bushman TL, Kuemmerle JF 1998 IGFBP-3 and IGFBP-5 production by human intestinal muscle: reciprocal regulation by endogenous TGF-beta 1. Am J Physiol 275:G1282-G1290

12. Williams AC, Collard TJ, Perks CM, Newcomb P, Moorghen M, Holly JM, Paraskeva C 2000 Increased p53-dependent apoptosis by the insulin-like growth 
factor binding protein IGFBP-3 in human colonic adenoma-derived cells. Cancer Res 60:22-27

13. Alami N, Page V, Yu QN, Jerome L, Paterson J, Shiry L, Leyland-Jones B 2008 Recombinant human insulin-like growth factor-binding protein 3 inhibits tumor growth and targets the Akt pathway in lung and colon cancer models. Growth Horm IGF Res 18:487-496

14. Haston CK, Cory S, Lafontaine L, Dorion G, Hallett MT 2006 Strain-dependent pulmonary gene expression profiles of a cystic fibrosis mouse model. Physiol Genomics 25:336-345

15. O'Brien TJ, Létuvé S, Haston CK 2005 Radiation-induced strain differences in mouse alveolar inflammatory cell apoptosis. Can J Physiol Pharmacol 83:117-122

16. Rajah R, Valentinis B, Cohen P 1997 Insulin-like growth factor (IGF)-binding protein-3 induces apoptosis and mediates the effects of transforming growth factorbeta 1 on programmed cell death through a p53- and IGF-independent mechanism. J Biol Chem 272:12181-12188

17. Taylor AM, Bush A, Thomson A, Oades PJ, Marchant JL, Bruce Morgan C, Holly J, Ahmed L, Dunger DB 1997 Relation between insulin-like growth factor-I, body mass index, and clinical status in cystic fibrosis. Arch Dis Child 76:304-309

18. Rosenberg LA, Schluchter MD, Parlow AF, Drumm ML 2006 Mouse as a model of growth retardation in cystic fibrosis. Pediatr Res 59:191-195

19. Street ME, Ziveri MA, Spaggiari C, Viani I, Volta C, Grzincich GL, Virdis R, Bernasconi S 2006 Inflammation is a modulator of the insulin-like growth factor (IGF)/IGF-binding protein system inducing reduced bioactivity of IGFs in cystic fibrosis. Eur J Endocrinol 154:47-52

20. Bijvelds MJ, Bronsveld I, Havinga R, Sinaasappel M, de Jonge HR, Verkade HJ 2005 Fat absorption in cystic fibrosis mice is impeded by defective lipolysis and post-lipolytic events. Am J Physiol Gastrointest Liver Physiol 288:G646-G653

21. Booth CC, Evans KT, Menzies T, Street DF 1959 Intestinal hypertrophy following partial resection of the small bowel in the rat. Br J Surg 46:403-410

22. Albiston AL, Taylor RG, Herington AC, Beveridge DJ, Fuller PJ 1992 Divergent ileal IGF-I and IGFBP-3 gene expression after small bowel resection: a novel mechanism to amplify IGF action? Mol Cell Endocrinol 83:R17-R20

23. Gillingham MB, Kritsch KR, Murall SG, Lund PK, Ney DM 2001 Resection upregulates the IGF-I system of parenterally fed rats with jejunocolic anastomosis. Am J Physiol Gastrointest Liver Physiol 281:G1158-G1168

24. Edmondson SR, Thumiger SP, Kaur P, Loh B, Koelmeyer R, Li A, Silha JV, Murphy LJ, Wraight CJ, Werther GA 2005 Insulin-like growth factor binding protein-3 (IGFBP-3) localizes to and modulates proliferative epidermal keratinocytes in vivo. Br J Dermatol 152:225-230

25. Cianfarani S, Geremia C, Puglianiello A, Maiorana A, Germani D 2007 Late effects of disturbed IGF signaling in congenital diseases. Endocr Dev 11:16-27
26. Vrieling A, Voskuil DW, Bosma A, Majoor DM, van Doorn J, Cats A, Depla AC, Timmer R, Witteman BJ, Wesseling J, Kampman E, Van't Veer LJ 2009 Expression of insulin-like growth factor system components in colorectal tissue and its relation with serum IGF levels. Growth Horm IGF Res 19:126-135

27. Garrison AP, Dekaney CM, von Allmen DC, Lund PK, Henning SJ, Helmrath MA 2009 Early but not late administration of glucagon-like peptide-2 following ileocecal resection augments putative intestinal stem cell expansion. Am J Physiol Gastrointest Liver Physiol 296:G643-G650

28. Murali SG, Liu X, Nelson DW, Hull AK, Grahn M, Clayton MK, Pintar JE, Ney DM 2007 Intestinotrophic effects of exogenous IGF-I are not diminished in IGF binding protein-5 knockout mice. Am J Physiol Regul Integr Comp Physiol 292:R2144R2150

29. Cheung QC, Yuan Z, Dyce PW, Wu D, DeLange K, Li J 2009 Generation of epidermal growth factor-expressing Lactococcus lactis and its enhancement on intestinal development and growth of early-weaned mice. Am J Clin Nutr 89:871-879

30. Norkina O, Burnett TG, De Lisle RC 2004 Bacterial overgrowth in the cystic fibrosis transmembrane conductance regulator null mouse small intestine. Infect Immun 72:6040-6049

31. Canale-Zambrano JC, Auger ML, Haston CK 2010 Toll-like receptor-4 genotype influences the survival of cystic fibrosis mice. Am J Physiol Gastrointest Liver Physiol 299:G381-G390

32. de Lisle RC, Sewell R, Meldi L 2010 Enteric circular muscle dysfunction in the cystic fibrosis mouse small intestine. Neurogastroenterol Motil 22:341-e87

33. Holzenberger M, Hamard G, Zaoui R, Leneuve P, Ducos B, Beccavin C, Périn L, Le Bouc Y 2001 Experimental IGF-I receptor deficiency generates a sexually dimorphic pattern of organ-specific growth deficits in mice, affecting fat tissue in particular. Endocrinology 142:4469-4478

34. Colangelo LA, Liu K, Gapstur SM 2004 Insulin-like growth factor-1, insulin-like growth factor binding protein-3, and cardiovascular disease risk factors in young black men and white men: the CARDIA Male Hormone Study. Am J Epidemiol 160:750-757

35. Sídlová K, Pechová M, Kotaska K, Průsa R 2002 Insulin-like growth factor binding protein-3 in patients with liver cirrhosis. Physiol Res 51:587-590

36. Guilherme A, Virbasius JV, Puri V, Czech MP 2008 Adipocyte dysfunctions linking obesity to insulin resistance and type 2 diabetes. Nat Rev Mol Cell Biol 9:367-377

37. Bannerjee K, Camacho-Hübner C, Babinska K, Dryhurst KM, Edwards R, Savage MO, Sanderson IR, Croft NM 2004 Anti-inflammatory and growth-stimulating effects precede nutritional restitution during enteral feeding in Crohn disease. J Pediatr Gastroenterol Nutr 38:270-275 